\title{
Geochemistry and Petrogenesis of Intrusive Pluton in North of Golpayegan (Central Part of Sanandaj-Sirjan Zone)
}

\author{
Marzieh Shahpari ${ }^{*}$, Afshin Ashja Ardalan', Mohammad Hashem Emami², \\ Mohammad Ali Arian', Abdollah Yazdi ${ }^{3}$ \\ ${ }^{1}$ Department of Geology, Faculty of Sciences, North Tehran Branch, Islamic Azad University, Tehran, Iran \\ ${ }^{2}$ Department of Geology, Eslamshahr Branch, Islamic Azad University, Eslamshahr, Iran \\ ${ }^{3}$ Department of Geology, Kahnooj Branch, Islamic Azad University, Kerman, Iran \\ Email: ${ }^{\text {marziehshahpari@yahoo.com }}$
}

Received 19 July 2014; revised 15 August 2014; accepted 11 September 2014

Copyright (C) 2014 by authors and Scientific Research Publishing Inc.

This work is licensed under the Creative Commons Attribution International License (CC BY).

http://creativecommons.org/licenses/by/4.0/

c) (i) Open Access

\begin{abstract}
Granitoid pluton in the north of Golpayegan is located in $10 \mathrm{~km}$ north of Golpayegan at SanandajSirjan zone. Dominant rocks of this region include granite, syenite, and gabbro. Granite type is granular with medium to coarse crystals and its mineralogical composition contains alkali feldspar + quartz + plagioclase + biotite + secondary minerals (opaque + sphene + apatite). Granite rocks have calc-alkaline and metaluminous to peraluminous nature, relative enrichment of $R b$ over Sr, and relative enrichment of LILE over HFSE elements. These granites, which are type I, are derived from the melting of metagreywackes and their tectonic setting is of upper continental crust and post-orogenic setting. Gabbroic type is older than other types of the pluton and is granular with medium to fine crystal. Mineralogical composition of these rocks is plagioclase + pyroxene + amphibole + biotite + secondary minerals (opaque). Based on geochemical characteristics of tholeiitic and metaluminous nature, relative enrichment of Ba and $\mathrm{Sr}$ elements over $\mathrm{Rb}$, relative enrichment of LILE elements over HFSE, negative anomaly of $\mathrm{Nb}$, $\mathrm{Ba}$, and $\mathrm{Ta}$, and positive anomaly of $\mathrm{Pb}$ are observed. Origin of this type is probably from enriched mantle and in-plane tectonic setting.
\end{abstract}

\section{Keywords}

Granitoid, Sanandaj-Sirjan Zone, Golpayegan

\footnotetext{
${ }^{*}$ Corresponding author.
}

How to cite this paper: Shahpari, M., Ardalan, A.A., Emami, M.H., Arian, M.A. and Yazdi, A. (2014) Geochemistry and Petrogenesis of Intrusive Pluton in North of Golpayegan (Central Part of Sanandaj-Sirjan Zone). Open Journal of Geology, 4, 481-494. http://dx.doi.org/10.4236/ojg.2014.49035 


\section{Introduction}

Intrusive pluton in the north of Golpayegan crops out in a region between longitude of $50^{\circ} 15^{\prime}$ and $50^{\circ} 20^{\prime}$ east and latitude of $33^{\circ} 33^{\prime}$ and $33^{\circ} 35^{\prime}$ north in the central area of Sanandaj-Sirjan zone (Figure 1). The studied area is located in the northwest of Isfahan province and south of Central province. The first study which has been performed on this zone is in the form of 1:250,000 detailed geological map by Tiele [1], in which rocks of the region are divided into metamorphic, plutonic and volcanic rocks. In the past, the studied area and its surrounding regions have been studied by different researchers such as Ebrahimi [2], Sharifi [3] and Ahmadi [4]. Stocklin [5], Tiele [1], and Ibrahimi [2] have considered Precambrian age as the metamorphism of this region. According to the studies by Sharifi [3], metamorphic age of this region is considered to include slate, calc-schist, metadolostone (Paleozoic), amphibolites, chlorite schist, metavolcanic (Mesozoic), and metagranite (Cretaceous-Paleocene). Therefore, intrusive bodies in the north of Golpayegan, which have cut the above-mentioned metamorphic rocks, definitely do not belong to Precambrian, and the alternative age of the intrusive bodies located in Golpayegan - east of Khomein is considered to be Mesozoic. Furthermore, age determination by K-Ar radiometry demonstrates that age of granite in Esfajerd is around 64.2 million years and that granites on the east of Cheshme Sefid have been injected around 58.4 million years ago, which represents their Cretaceous age [6].

\section{Geology of the Studied Pluton}

Sanandaj-Sirjan zone is a narrow strip of land on the southwest of Central Iran which is located at the immediate northeast of Major Zagros Thrust. Rock and structural characteristics of Sanandaj-Sirjan zone represent a deep trough or middle block split in Iran and Arabia Precambrian shield. Therefore, its geological characteristics are evidently different from those of the surrounding zones [7]. Sanandaj-Sirjan zone is like a metamorphic strip with a northwest-southeast trend in parallel to Zagros zone which is extended to Taurus zone in Turkey with similar characteristics. In this zone, several intrusive igneous phases have occurred, the most important of which have been at Middle-Late Triassic, Late Jurassic_Early Cretaceous, Late Cretaceous-Paleocene [8]. Most of the plutons of Golpayegan-Urmia set are of composite plutons, which include rocks with different compositions and ages. In this intrusive set, most bodies belong to Cretaceous-Paleocene period. In most of the composite plutons of this set, formation of basic rocks has priority over that of acidic rocks and distinct differences in the rock composition of this set indicates different origins of each rock group [9]. In some part of these intrusive sets, alkalisyenite-granitehas been also observed. Imami [10] believes that there are some magma rocks in Iran which have appeared between two Jurassic and Cretaceous periods and have been attributed to both periods. Among these rocks at Sanandaj-Sirjan zone are granite-granodiorite bodies at Golpayegan zone. Berberian and King [11] state that translocation of acidic plutonic bodies in Middle Jurassic and Late Cretaceous-Tertiary (Golpayegan-Urmia intrusive belt) in the southern margin of Central Iran (Sanandaj-Sirjan zone) is the result of continued subduction and its final stages.

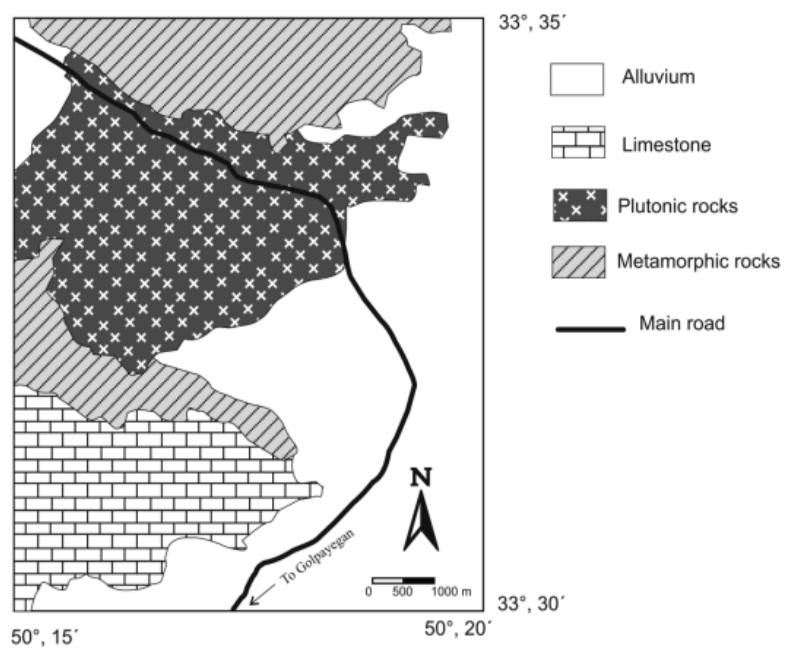

Figure 1. Map of the study population [28]. 
Intrusive pluton in the north of Golpayegan is located in the central region of Sanandaj-Sirjan zone and is considered as a part of Tethys orogeny. The studied pluton can be divided into four parts in terms of petrology and field relations; different units of the petrology of the studied pluton are cut by metamorphic and non-metamorphic dikes. Here, this pluton diversity is briefly introduced: 1-Gabbro type, 2-Granite type, 3-Syenite type, and 4-Monzonite type.

\subsection{Gabbro}

This rock which crops out of the Schists in form of apophyses in this region contains coarse plagioclase crystals that seem to be mostly secondary with a granular-subophitic texture under the microscope (Figure 2).

\subsection{Granite}

Granites of the region crop out in the north of syenite pluton and inside metamorphic Precambrian rocks and have caused contact metamorphism. In field studies, granites have mainly medium to coarse crystals and emerge in grey color in most of the cases. Granitoid rocks in the north of Golpayegan include syenogranite and monzogranite with silica veins at the margin of the pluton (Figure 3).

\subsection{Syenite}

Syenites and quartz syenites which constitute the main volume of plutonic rocks of the region are injected into regional metamorphic rocks and cause contact metamorphism in them. These rocks which mainly crop out around Khomein-Golpayegan road are grey in the hand specimens. Syenite rocks contain different petrological sets from alkaline syenites to syenite.

\subsection{Monzonite}

These rocks appear in grey color in the hand sample.

\subsection{Metamorphic and Non-Metamorphic Dikes}

In this region, due to the presence of magmatism in multiple phases, dikes with the existing type of bodies are observed which are sometimes metamorphic and some other times non-metamorphic. Presence of rocks that are more basic than meatgranitoid and quartz syenite such as monzonite and gabbro (as xenolite) and fine-grained dikes of quartz syenite suggests the injection of magma at multiple stages (Figure 4).

\section{Petrography}

Gabbro has a granular-subophitic texture and its mineralogical composition contains plagioclase, clinopyroxene, amphibole, biotite, and secondary minerals (primary opaque, zircon, sphene, and apatite). Clinopyroxene appears in the form of euhedral and semi-euhedral crystals, which are extensively transforming into tremolite-actinolite and biotite (Figure 5(a)).

Granites of this region contain mineralogical composition of alkali feldspath, plagioclase, quartz, biotite, amphibole, and other minerals (apatite, sphene, and zircon). Perthite is abundantly present in these rocks (Figure 5(b)). Quartz is seen as anhedral crystals with occasional crystallization (Figure 5(c)). Apatite and sphene are also observed as inclusions and accessory in these rocks, respectively (Figure 5(d)).

Mineralogical composition of alkaline syenites includes alkali feldspar, plagioclase, amphibole, and accessory minerals (apatite and sphene). Texture of these rocks is granular, porphyric with medium-sized grains. Alkali feldspar are mostly perthit or with little microcline.

Mineralogical composition of the syenites of this region includes alkali feldspar, plagioclase, amphibole, quartz, and accessory minerals (apatite, sphene, zircon, and primary opaque). Perthit or it are abundantly found in these rocks (Figure 5(e)). Some plagioclase crystals are intact and some others are partially altered to kaolinite. Composition of plagioclases of these rocks is at the andesine level (based on Michel-Levy's table with the extinction angle of $23^{\circ}$ ) (Figure 5(f)). Zircon is rarely seen in these rocks (Figure 5(g)).

Monzonite rocks are granular with frequent inclination to intergranular and porphyric with medium grains inclined to microlite. Alkali feldspath, plagioclase, amphibole, quartz, and secondary and accessory minerals 


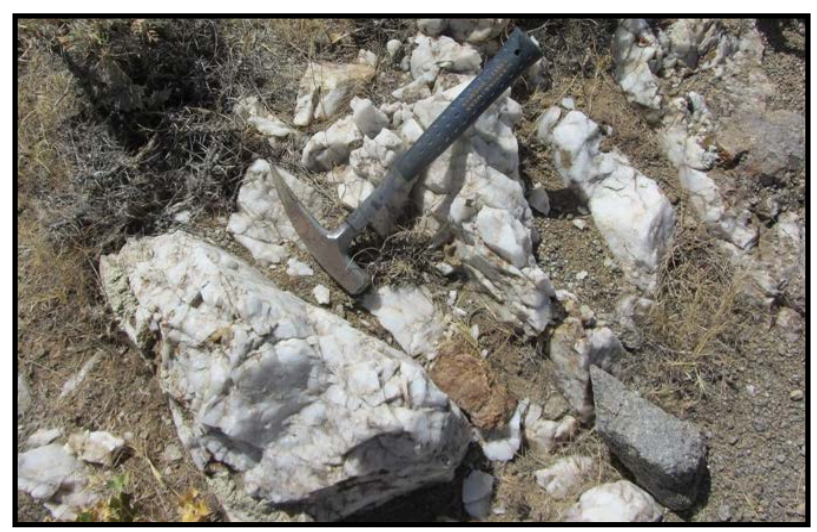

Figure 2. Filling fractured quartz veins are relatively pure $(\mathrm{N}$ $33^{\circ} 34^{\prime} 28^{\prime \prime}-\mathrm{E} 50^{\circ} 13 ' 20^{\prime \prime}-\mathrm{H}: 2167 \mathrm{~m}$ ).

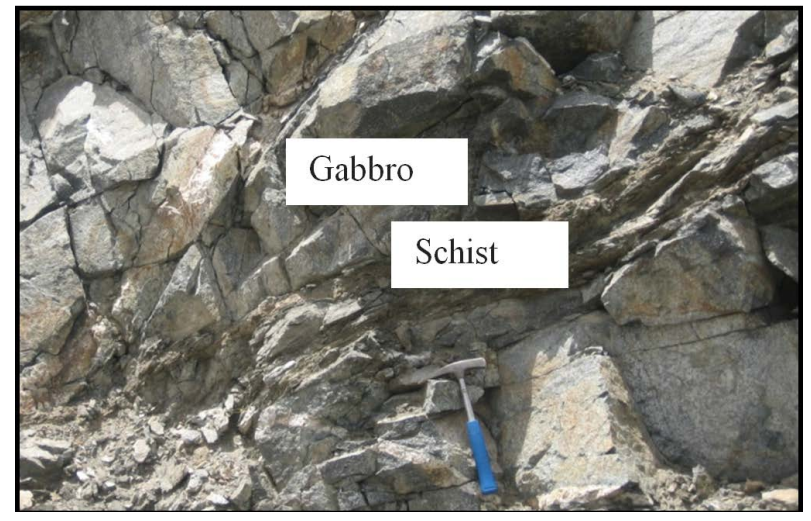

Figure 3. Gabbro out crop within the schists.

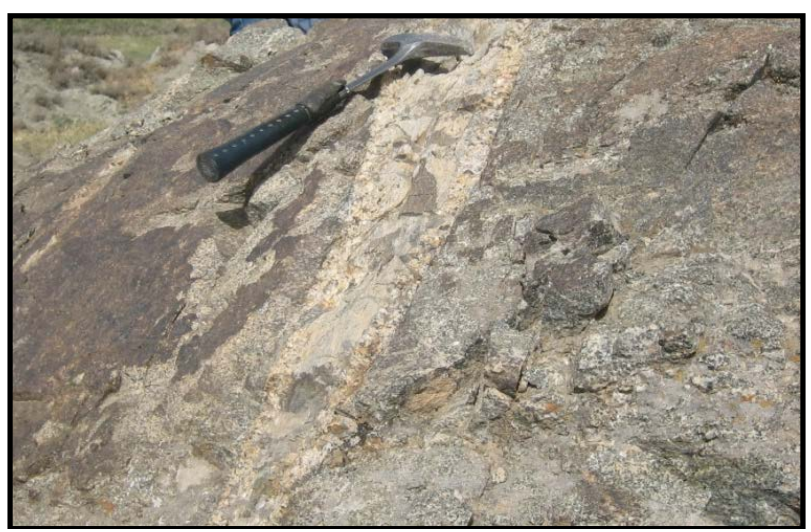

Figure 4. Syenite dyke metamorphic.

(apatite, sphene, zircon, and primary opaque) are among the constitutive minerals of these rocks.

\section{Geochemistry}

\subsection{Geochemistry of Primary and Rare Elements}

Variation rate of $\mathrm{SiO}_{2}$ is between $46 \%$ and $78 \%$. In Harker diagrams [12], samples are classified into three distinct ranges, demonstrating different primary magmas for each (Figure 6).

Rocks of tholeiitic gabbroic, syenite, and granite types are alkaline and metaalumin, tholeiitic and metalumin- 

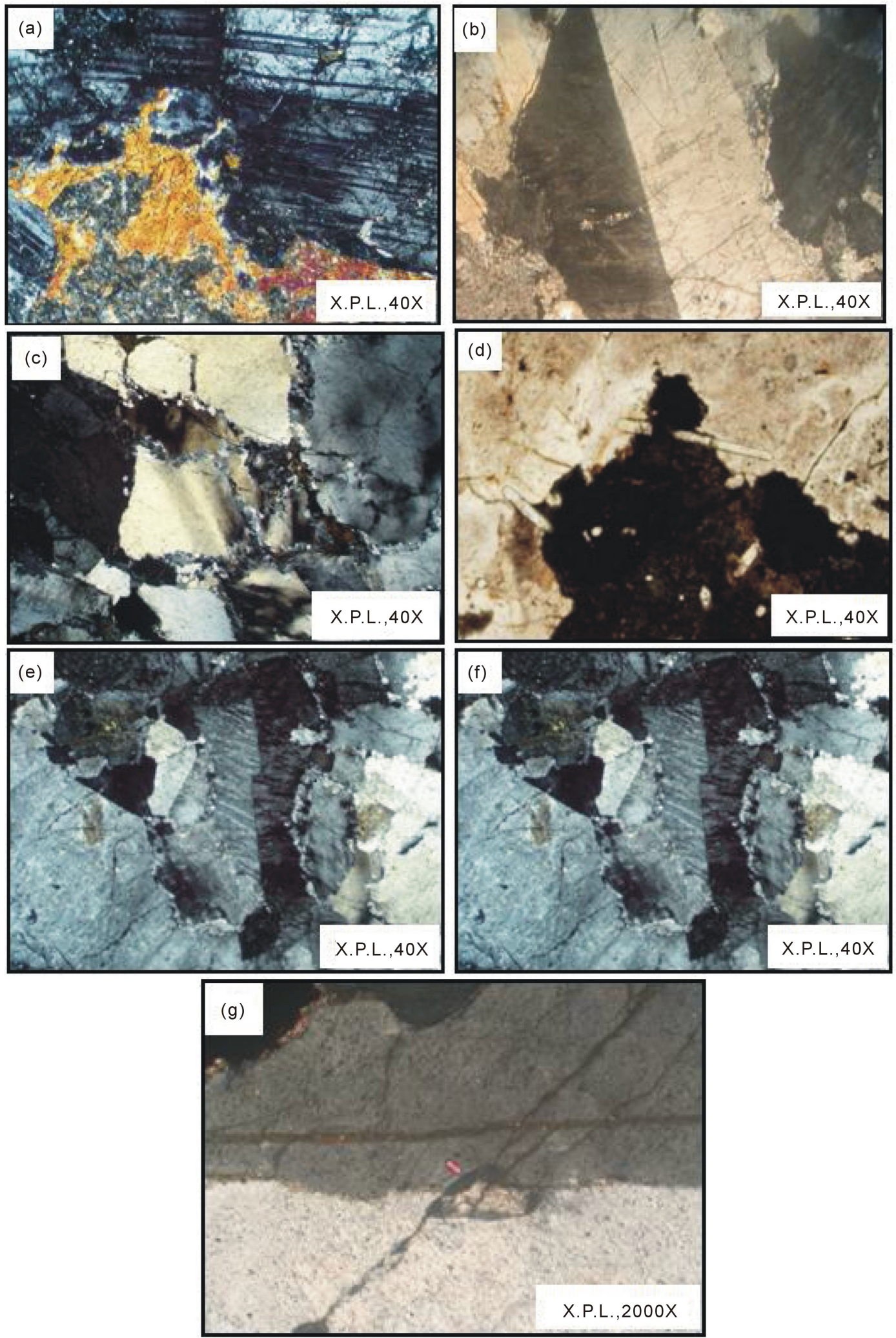

Figure 5. Selected microscopic images of rock groups studied (in crosspolarized light XPL): (a) Clinopyroxene; (b) Perthite; (c) Quartz recrystallization; (d) Apatite inclusionsin amphibole; (e) Perthite orthose; (f) Polysynthetic plagioclase; and g) Zircon. 

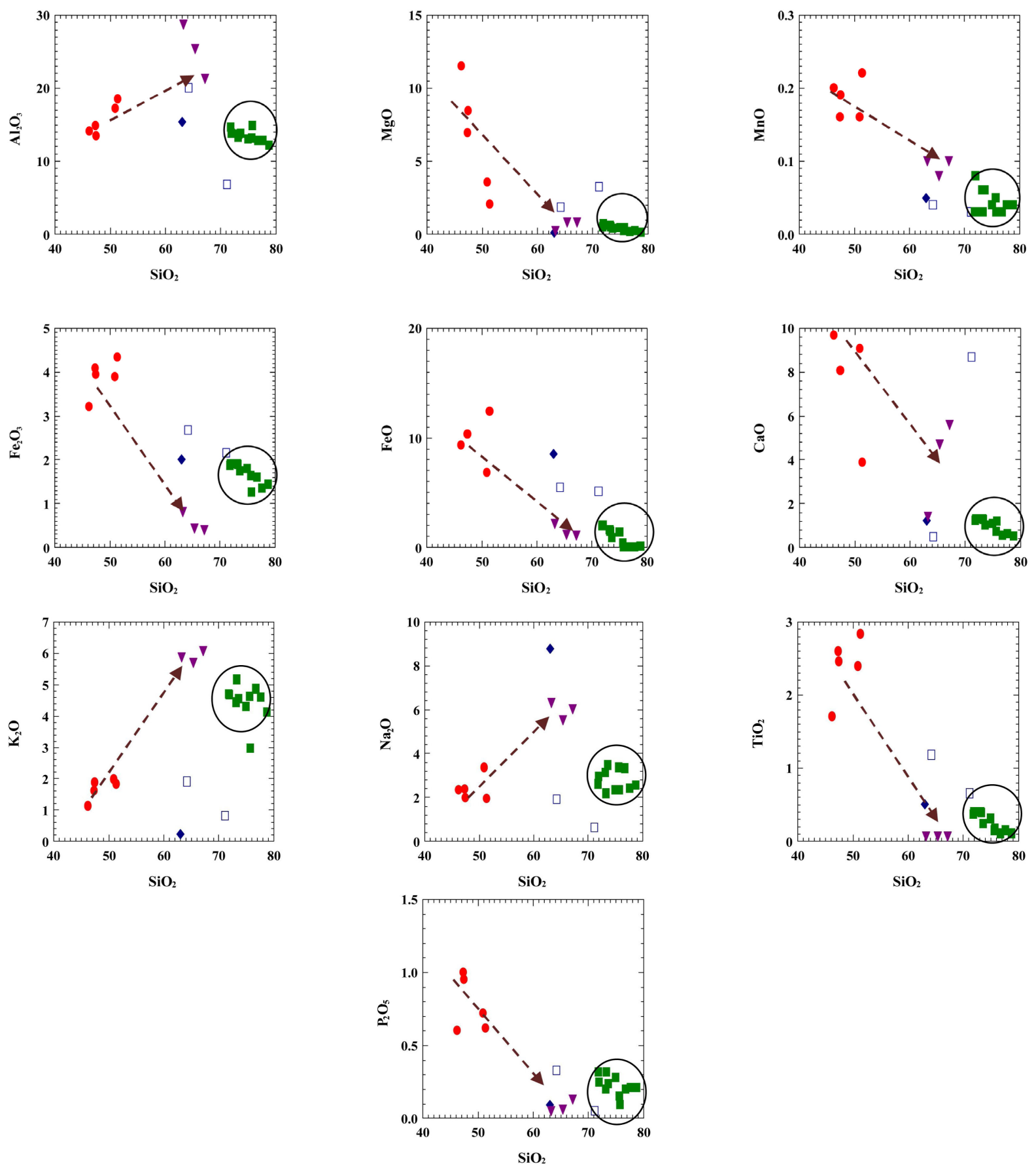

Figure 6. Change the major element oxides than silica (Harker diagrams) [12].

ous, and calc-alkaline and metaluminous to peraluminous, respectively.

According to Harker diagrams, igneous rocks of the region are classified into two groups. The first group belongs to gabbro-syenite family, the crystallization-magmatic differentiation trend of which justifies the role of element variations. The second group is granitoid family which is distinct and away from gabbro, has a different age, and shows a different behavior in geochemical diagrams.

Increasing amount of $\mathrm{SiO}_{2}$ justifies decreased levels of $\mathrm{MgO}, \mathrm{Fe}_{2} \mathrm{O}_{3}, \mathrm{FeO}, \mathrm{TiO}_{2}$, and $\mathrm{MnO}$ through the crystallization of amphibole and biotite ferromagnesian minerals, variations of $\mathrm{Al}_{2} \mathrm{O}_{3}$ and $\mathrm{CaO}$ through the crystallization of plagioclase, and decreased $\mathrm{P}_{2} \mathrm{O}_{5}$ through the crystallization of apatite. Linear and negative variation 
trends of $\mathrm{CaO}$ and $\mathrm{P}_{2} \mathrm{O}_{5}$ relative to $\mathrm{SiO}_{2}$ which are occasionally seen in the studied samples have been stated as the characteristics of type I granite [13], because phosphor available in type I granite acts as a compatible element due to the crystallization of apatite; indeed, in case other factors do not get involved in the intrusion or extrusion of these element. In the existing samples, a scattering is observed in a specific silica range in the gabbro and syenite samples, while continuity and proximity of data are seen in most of the granite samples. It seems that, in a specific range of silica, high variation of elements cannot be attributed to primary and magmatic differentiation processes, since they are crystallized in specific steps of the differentiation of particular minerals with determined distribution coefficients of rare elements. Abnormal increase in the level of several elements in a specific silica range clearly demonstrates the effect of secondary phenomena. In Harker diagrams related to rare elements, two rock groups can be distinguished similar to primary elements; the first one is gabbro-syenite family and the second is from granitoid family (Tables 1-3).

\subsection{Spider Diagrams of Incompatible Elements}

Concentrations of incompatible elements in rocks are normalized in relation to a specific standard which is typically chondrite meteorite; in this regard, REEs elements are specifically important. Normalization with respect to chondrites is considered important from two perspectives [14]; first, frequency variations of elements with even and odd atomic numbers are removed and second any separation of rare earth elements (REEs) with respect to chondrites can be easily detected. REEs are normalized according to Boynton data [15] which is widely accepted by most petrologists [14] (Figure 7).

Light rare earth elements (LREE) show a higher level of enrichment than high rare earth element (HREE), which is caused by one of the following factors: 1) low melting of mantle materials, 2) limited melting of enriched mantle, and 3) product of the final process of crystallization.

Eu negative anomaly is the result of the establishment of relative reduction conditions dominating its emergence and intrusion into feldspar structure; crystallization and the accompanying separation of feldspars cause this negative anomaly. Eu amount is substantially controlled by feldspats (especially in granitic magmas). In granitic magmas, $\mathrm{Eu}^{2+}$ is compatible with plagioclase and alkaline feldspath and their differentiation from granitic molten or their deposit on the origin leads to the formation of Eu negative anomaly [14] [16]. LREE enrichment over HREE can be due to the presence of magma at the primary stages of melting or final stages of differential crystallization and also presence of hornblendes in the molten of these rocks.

Presence of relative enrichment of LREE over HREE in diagrams related to the region's gabbros indicates relative enrichment of LREE incompatible elements in origin rocks; such an origin can be enriched or evolved mantle. Also, due to the higher level of apatite, titanite, and rutile blades, REE content is higher than that of other types.

In spider diagrams, all the samples are normalized according to primary mantle [17] (Figure 8).

The following cases are among the issues that should be taken into account when interpreting these diagrams:

1) Higher enrichment of LILE over HFSE elements; Kelement [18] proposes that depletion of HFS in magma reflects the interaction between magma and depleted peridotite.

2) Negative anomaly of $\mathrm{Bn}, \mathrm{Ba}, \mathrm{Zr}$, and $\mathrm{Lu}$ and positive anomaly of $\mathrm{Sm}, \mathrm{Nd}$, and $\mathrm{Th}$

According to Wilson [19] and Rollinson [14], Nb drop in the spider diagram of incompatible elements can be due to two factors: either magma impregnation with mantle materials or their relationship with subduction. $\mathrm{Nb}$ negative anomaly is the indicator of continental rocks and might indicate the involvement of crust in magma processes [14].

In granite and syenite rocks, enrichment of LILE over HFSE and negative anomaly of $\mathrm{Lu}, \mathrm{Ba}$, and $\mathrm{Zr}$ and positive anomaly of $\mathrm{Nd}$ and $\mathrm{Th}$ can be observed.

Concentration of other rare elements in Golpayegan'srocks is controlled by special minerals. For example, concentration of $\mathrm{Zr}, \mathrm{P}, \mathrm{Sr}, \mathrm{Ti}$, and $\mathrm{Nb}$ is controlled by zircon, apatite, plagioclase, ilmenite, and rutile, concentration of $\mathrm{Rb}, \mathrm{Cs}, \mathrm{Ba}, \mathrm{Na}, \mathrm{Ca}, \mathrm{Al}$, and $\mathrm{Si}$ is controlled by feldspats, and that of $\mathrm{Cr}, \mathrm{Co}, \mathrm{Ti}, \mathrm{Fe}$, and $\mathrm{Mg}$ is controlled by ferromagnesian minerals like biotite, respectively.

\section{Discussion}

\subsection{Magmatic Origin}

According to geochemical characteristics, the studied gabbro rocks have alkaline nature. Based on the spider 
Table 1. Chemical analysis of granite rocks of intrusive pluton in north of Golpayegan.

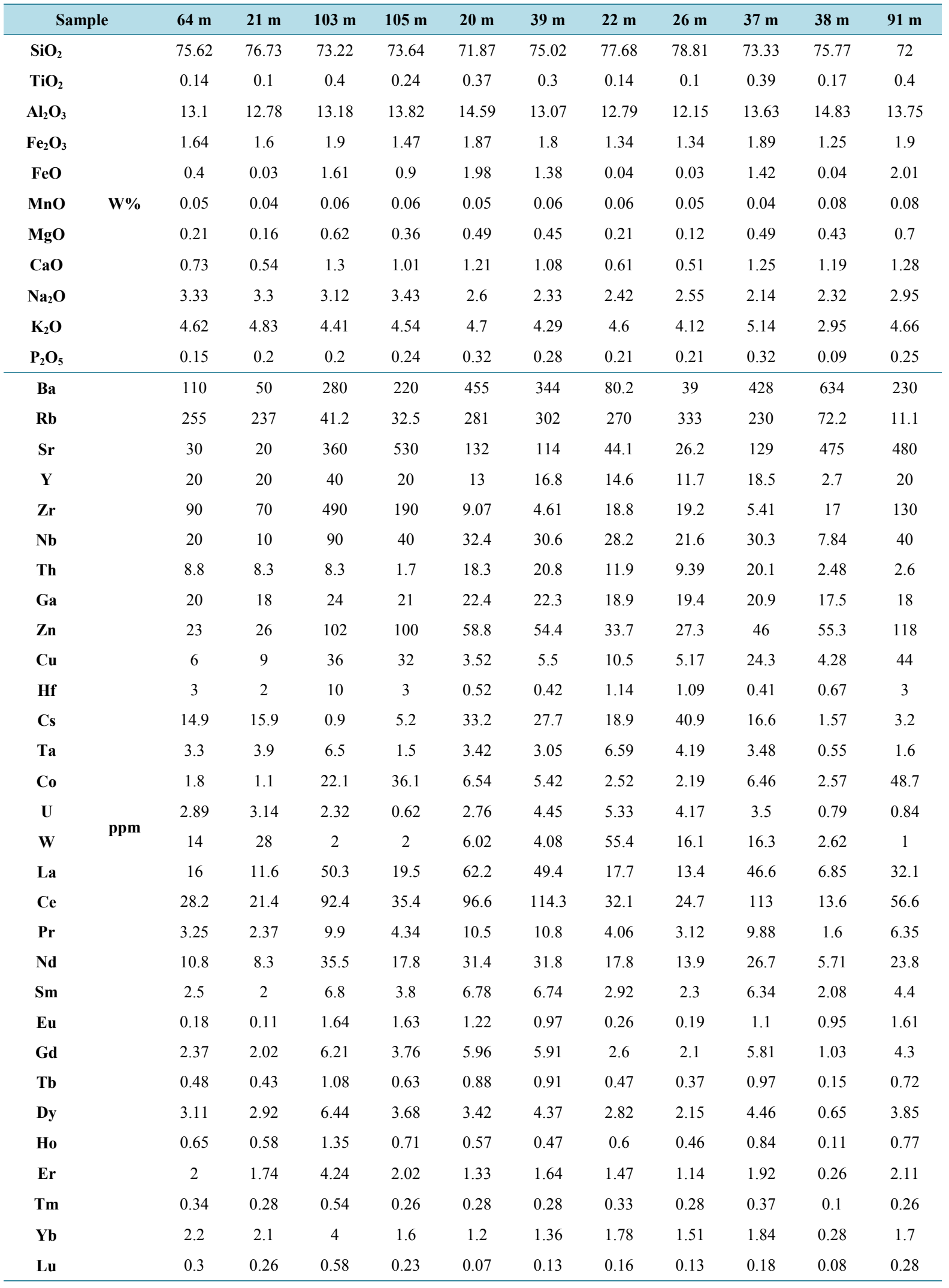


Table 2. Chemical analysis of gabbro rocks of intrusive pluton in north of Golpayegan.

\begin{tabular}{|c|c|c|c|c|c|c|}
\hline \multicolumn{2}{|c|}{ Sample } & $12 \mathrm{~m}$ & $11 \mathrm{~m}$ & $13 \mathrm{~m}$ & $30 \mathrm{~m}$ & $88 \mathrm{~m}$ \\
\hline $\mathrm{SiO}_{2}$ & & 51.33 & 47.51 & 50.9 & 47.41 & 46.2 \\
\hline $\mathrm{TiO}_{2}$ & & 2.83 & 2.45 & 2.39 & 2.59 & 1.7 \\
\hline $\mathbf{A l}_{2} \mathbf{O}_{3}$ & & 18.49 & 13.74 & 17.16 & 14.85 & 14.14 \\
\hline $\mathrm{Fe}_{2} \mathrm{O}_{3}$ & & 4.33 & 3.95 & 3.89 & 4.09 & 3.2 \\
\hline $\mathrm{FeO}$ & & 12.38 & 10.36 & 6.84 & 10.34 & 9.3 \\
\hline MnO & W\% & 0.22 & 0.19 & 0.16 & 0.16 & 0.2 \\
\hline MgO & & 2.04 & 8.45 & 3.57 & 6.93 & 11.5 \\
\hline $\mathrm{CaO}$ & & 3.88 & 8.07 & 9.06 & 8.08 & 9.67 \\
\hline $\mathrm{Na}_{2} \mathbf{O}$ & & 1.94 & 1.96 & 3.34 & 2.38 & 2.34 \\
\hline $\mathbf{K}_{2} \mathbf{O}$ & & 1.82 & 1.86 & 1.97 & 1.6 & 1.12 \\
\hline $\mathbf{P}_{2} \mathbf{O}_{5}$ & & 0.62 & 0.95 & 0.72 & 1 & 0.6 \\
\hline $\mathbf{B a}$ & & 326 & 146 & 179 & 371 & 300 \\
\hline $\mathbf{R b}$ & & 46.9 & 85 & 37.8 & 21.3 & 212 \\
\hline Sr & & 120 & 314 & 493 & 845 & 90 \\
\hline $\mathbf{Y}$ & & 58.1 & 31 & 32.3 & 20.4 & 20 \\
\hline $\mathrm{Zr}$ & & 114 & 15.9 & 280 & 26.6 & 230 \\
\hline $\mathbf{N b}$ & & 111 & 67.4 & 72.3 & 63.5 & 30 \\
\hline Th & & 10.6 & 8.82 & 9.18 & 3.25 & 18.6 \\
\hline $\mathbf{G a}$ & & 352 & 24 & 22.6 & 17.1 & 23 \\
\hline $\mathrm{Zn}$ & & 211 & 156 & 139 & 130 & 44 \\
\hline $\mathrm{Cu}$ & & 16.6 & 119 & 49 & 63 & 5 \\
\hline Hf & & 2.98 & 0.64 & 0.44 & 1.94 & 6 \\
\hline Cs & & 0.7 & 6.34 & 1.93 & 0.88 & 11.8 \\
\hline Ta & & 7.79 & 4.02 & 3.28 & 4.39 & 3.3 \\
\hline Co & & 3.88 & 67.6 & 33.7 & 50.3 & 4.7 \\
\hline $\mathbf{U}$ & & 2.2 & 2.06 & 2.5 & 0.97 & 7.84 \\
\hline $\mathbf{W}$ & ppm & 1.19 & 1.54 & 2.05 & 0.33 & 4 \\
\hline $\mathbf{L a}$ & & 108 & 49.7 & 34.6 & 37.8 & 43.1 \\
\hline $\mathrm{Ce}$ & & 147 & 112 & 53.8 & 78.5 & 82.9 \\
\hline Pr & & 17.3 & 11.9 & 6.95 & 9.36 & 9.04 \\
\hline Nd & & 53.9 & 72.7 & 33.5 & 36.3 & 32.3 \\
\hline $\mathrm{Sm}$ & & 12.3 & 9.14 & 5.54 & 6.64 & 6.2 \\
\hline Eu & & 1.66 & 2.42 & 1.52 & 2.02 & 0.57 \\
\hline Gd & & 12.5 & 9 & 5.68 & 5.69 & 5.05 \\
\hline $\mathbf{T b}$ & & 2.27 & 1.46 & 1.11 & 0.88 & 0.84 \\
\hline Dy & & 12.3 & 6.77 & 5.57 & 4.74 & 4.09 \\
\hline Ho & & 2.72 & 1.47 & 1.29 & 0.96 & 0.82 \\
\hline $\mathbf{E r}$ & & 6.42 & 3.28 & 3.26 & 2.22 & 2.2 \\
\hline Tm & & 1.22 & 0.65 & 0.73 & 0.36 & 0.3 \\
\hline $\mathbf{Y b}$ & & 5.67 & 3.03 & 3.51 & 2.08 & 2 \\
\hline $\mathbf{L u}$ & & 0.54 & 0.31 & 0.32 & 0.26 & 0.36 \\
\hline
\end{tabular}


Table 3. Chemical analysis of syeniti and monzonite rocks of intrusive pluton in north of Golpayegan.

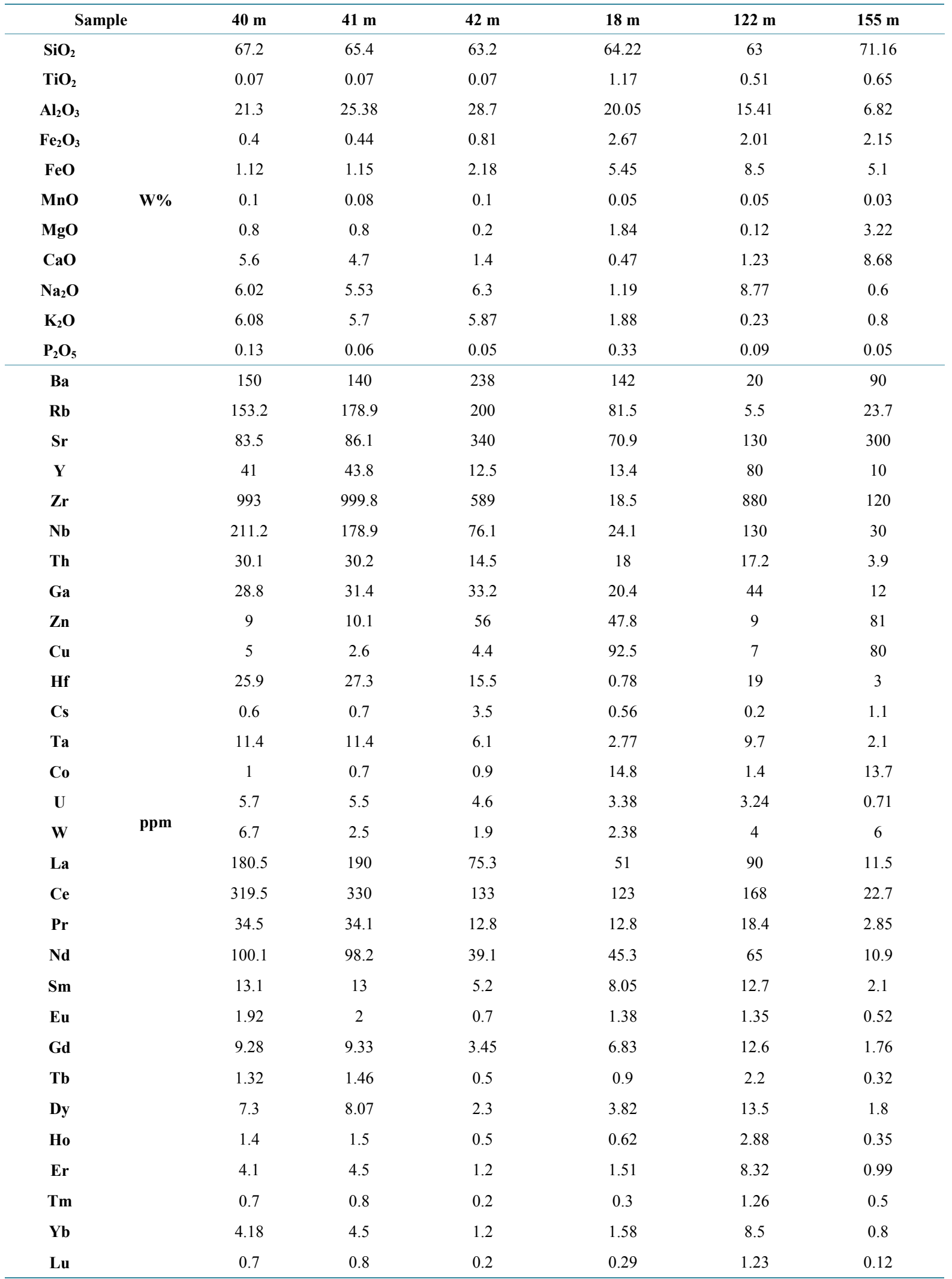



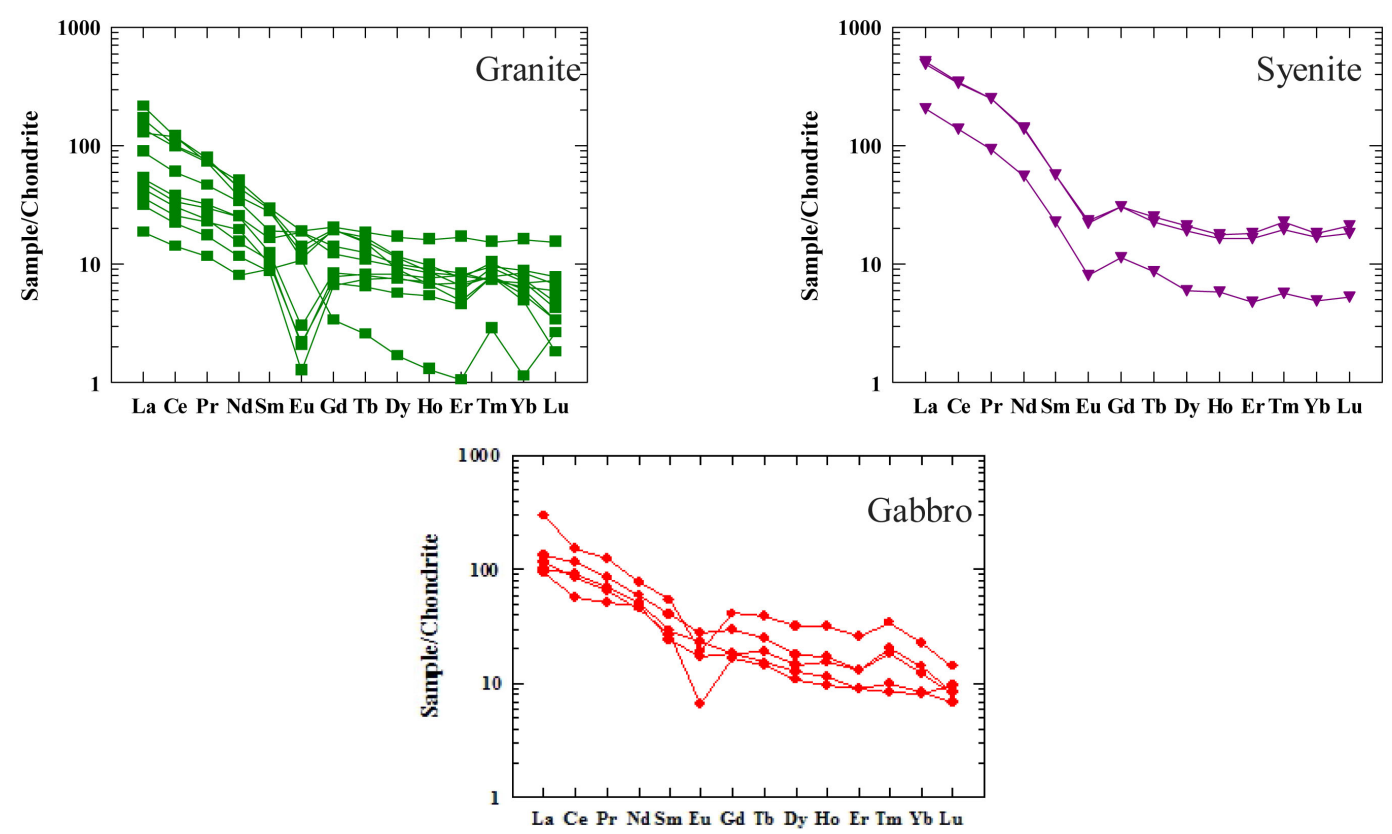

Figure 7. Normalized REE patterns relative to Chondrite.
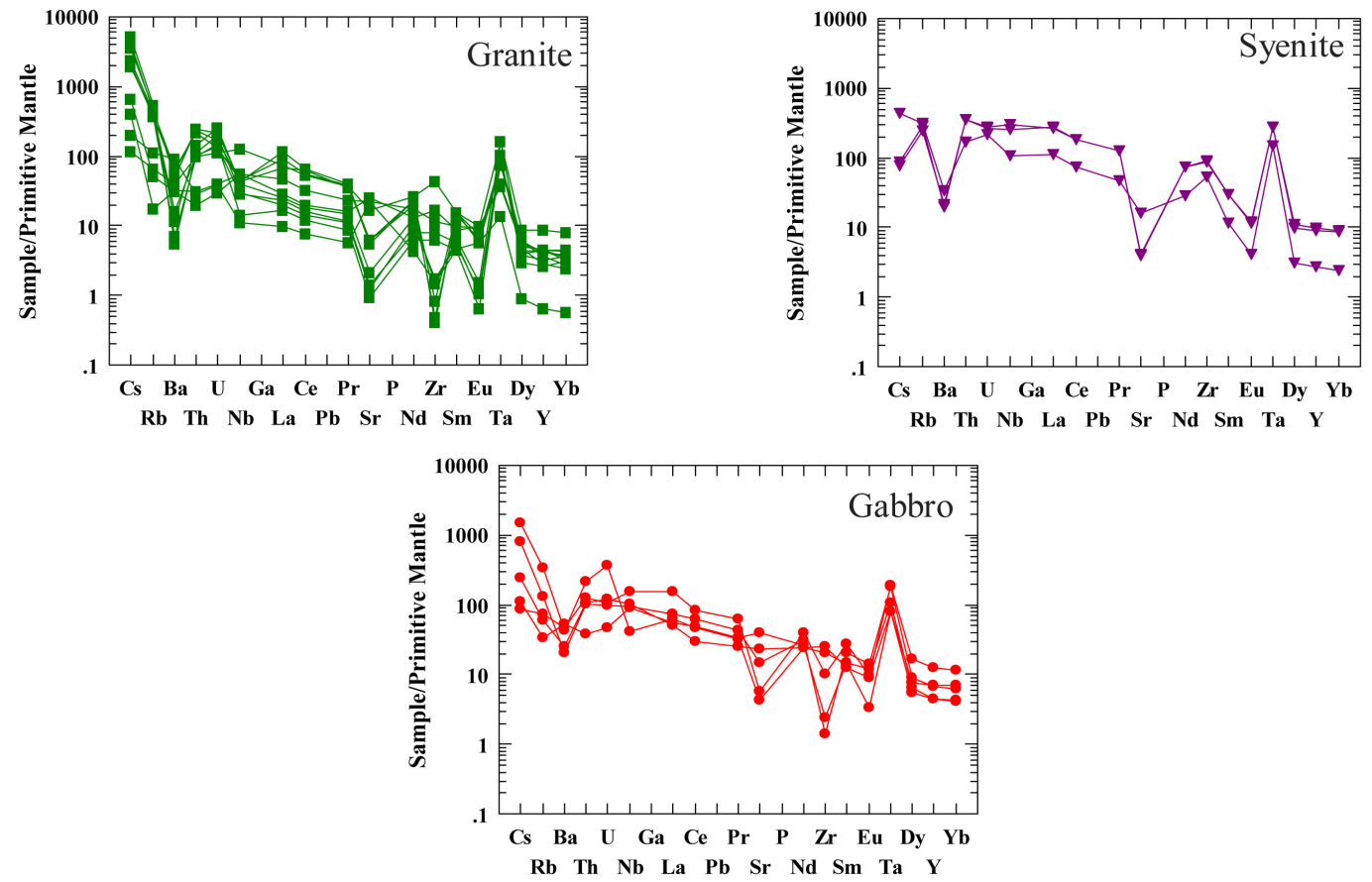

Figure 8. Frequency of spider diagrams normalizedin compatible elements relative to Primitive Mantle.

diagrams, these rocks of LILE elements are enriched over HFSE elements and Nb negative anomaly is observed in them. Gabbro rocks contain a high level of $\mathrm{MgO}$ which demonstrates their crystallization from a primary basic magma. Relative enrichment of $\mathrm{CaO}$ and $\mathrm{Sr}$ elements, relatively high level of $\mathrm{Al}_{2} \mathrm{O}_{3}$, and their metaalumin nature indicate high-temperature condition at their origin. Primary mantle rocks, transformed lithosphere mantle, and primary gabrro rocks in deep crust are considered as the source or origin rock for this type. For the formation of low-silica metaalumin molten by melting without water of metabasaltic origin, more than $1100^{\circ} \mathrm{C}$ temperature is required [20]. In case of the presence of such temperature at origin, such molten is characterized by 
low $\mathrm{Mg} \#<44\left(\mathrm{MgO}+0.9 \mathrm{FeOT}^{*} 100\right)$ and high $\mathrm{Na}_{2} \mathrm{O}>4.3 \mathrm{wt} \%$ [9]. Gabbro rocks of this type do not have such a characteristic. In order to identify the presence or absence of enrichment at the origin of studied mafic rocks, ratios of $\mathrm{Zr}-\mathrm{Nb}$ incompatible elements are used, in which mafic magma constituting the studied rocks is originated from an enriched mantle source (Figure 9(a)).

According to Chappell and White [21], classification regarding granite rocks, north Golpayegan's felsic rocks are of type I based on the following field and mineralogical observations:

- Lack of aluminium silicate minerals including muscovite, andalousite, cordierite, and garnet.

- These rocks are weak peraluminous which is among the characteristics of type I granite.

- Presence of hornblendes in the mineralogical composition of granites.

- Lack of mica-enriched and metamorphism enclaves.

- Presence of primary titanites and lack of monazite.

- Positive relationship of Th variations against $\mathrm{SiO}_{2}$.

- $\mathrm{P}_{2} \mathrm{O}_{5}$ diagram with respect to $\mathrm{SiO}_{2}$ for the studied samples shows a negative trend which is regarded among the characteristics of type I granite [13].

Using the diagrams introduced by Patino Douce [22], origin of granites can be attributed to the melting of metagreywackes (Figure 9(b)). Establishment of mafic magma with high temperature beneath the continental crust is the main factor for melting and producing a high amount of falsic magma.

\subsection{Tectonic Setting}

According to $\mathrm{Rb}-(\mathrm{Y}+\mathrm{Nb})$ diagram [23], the studied granite is located within WPG and VAG ranges (Figure 11(a)). In Pearce's diagrams, when the granite samples are located at WPG and VAG boundaries, they are most probably related to POG post-orogeny period. Furthermore, medium composition of upper continental crust (UCC position) is also added to this diagram [24] (Figure 10(a)). In Maniar and Piccoli's [25] diagrams (FeOt/(FeOt +

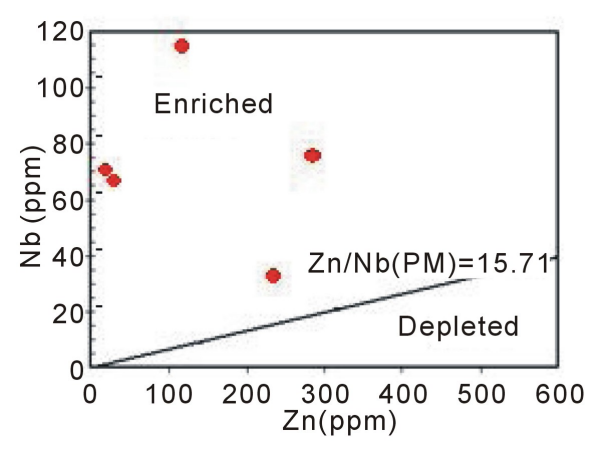

(a)

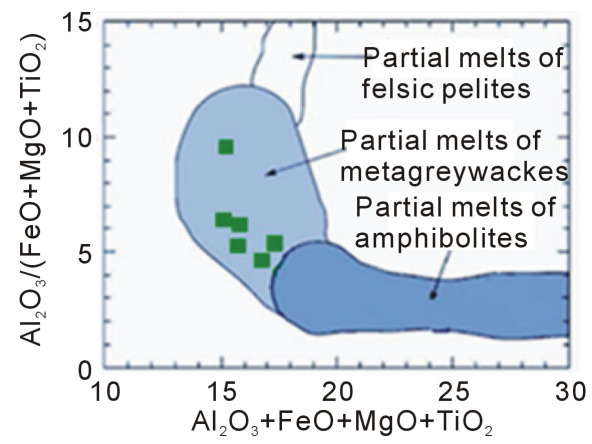

(b)

Figure 9. The Origins: (a) Determine the origin of enriched and depleted gabbro [17]; (b) Deter- mine the origin of the granitoid [22].

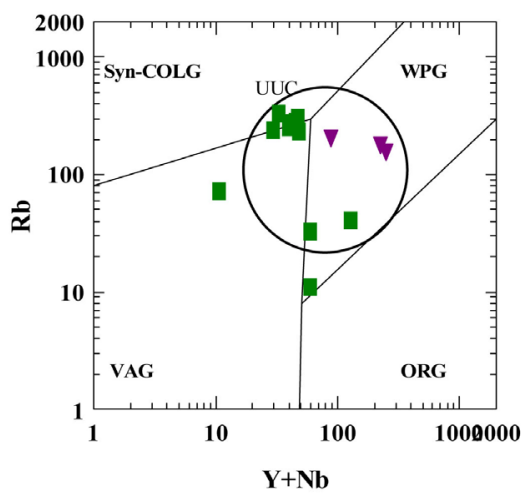

(a)

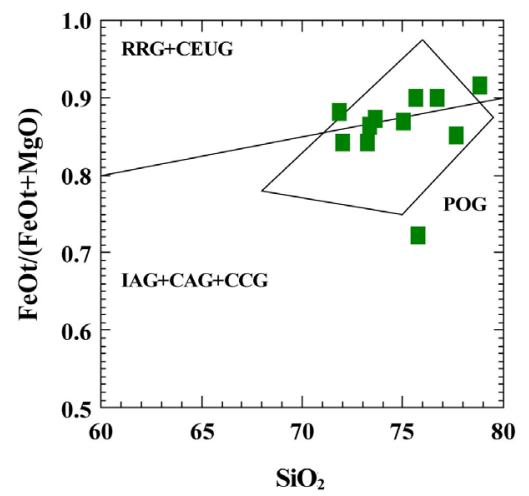

(b)

Figure 10. Graphs distinct tectonic granitoid: (a) [23]; (b) [25]. 


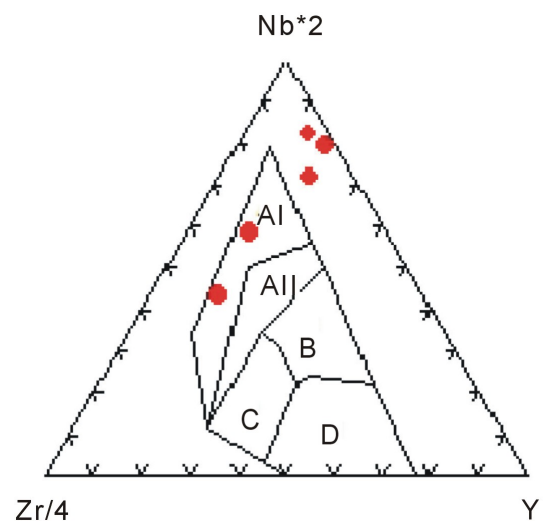

(a)

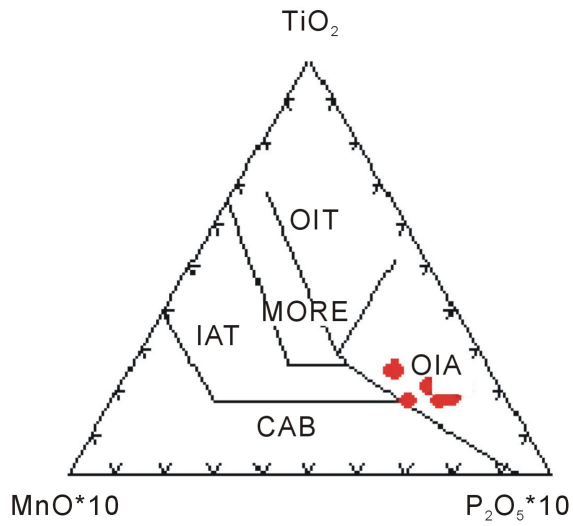

(b)

Figure 11. Graphs distinct tectonic gabbros: (a) Diagram Zr-Nb-Y [27]; (b) Diagram $\mathrm{MnO}-\mathrm{TiO}_{2}-\mathrm{P}_{2} \mathrm{O}_{5}$ [26].

$\mathrm{MgO}$ vs. $\mathrm{SiO}_{2}$ ), the studied granite samples belong to post-orogeny granite (POG) (Figure 10(b)).

In $\mathrm{MnO}-\mathrm{TiO}_{2}-\mathrm{P}_{2} \mathrm{O}_{5}$ [26] and $\mathrm{Zr}-\mathrm{Nb}-\mathrm{Y}$ [27] diagrams, gabbro samples are located within in-plane range (Figure 11).

\section{Conclusion}

The above investigations show that magmatism in the north of Golpayegan has been the result of a very complex subduction so that suture zone is accompanied by alkaline magmatic activities after orogeny and tectonic collision and eruption after the formation of a very thick crust. This magmatism is of post-orogeny and postcollision type and is related to tensile fractures after orogenic phases.

\section{References}

[1] Thiele, O., et al. (1968) Explanatory Text of the Golpaygan Quadrangle Map 1:250,000. Geological Survey of Iran, No. E7, Tehran.

[2] Ebrahimi, M. (1991) Survey of Geology and Petrology of the Igneous Rocks Golpayegan Mrq-White Springs. Graduate Thesis, Tehran University, Tehran.

[3] Sharifi, M. (1997) Geology and Petrology of Metamorphic and Igneous Rocks in the North East Golpayegan. Master's Thesis, University of Isfahan, Isfahan.

[4] AhmadiKhalaj, A. (1999) Evaluation Petrology and petrofabric of intrusive and metamorphic of Borogerd area. Master's Thesis, Tehran University, Tehran.

[5] Stocklin, J. (1968) Structural History and Tectonics of Iran: A Review. American Association of Petroleum Geologists Bulletin, 52, 1229-1258.

[6] Hassanzadeh, J. (2013) Conference GSI-Geochronology in Geological Survey of Iran.

[7] Aghanabati, A. (2006) Geology of Iran, Geological Survey and Mineral Exploration. Country Publications, Tehran.

[8] Moinvaziri, H. And Ahmadi, A. (1996) Petrography and Petrology of Igneous Rocks. Teacher Training University Press, Tehran.

[9] Ghalamghash, J. (2002) Petrology of the Intrusive Rocks Branch-Oshnoyeh Fit into Their Works. Ph.D. Thesis, Shahid Beheshti University, Tehran.

[10] Emami, M.H. (2000) Quarterly Journal of Earth Sciences, 12, 203-214.

[11] Berberian, M. and King, G.C.P. (1981) Towards a Pale Geography and Tectonic Evaluation of Iran. Canadian Journal of Earth Sciences, 18, 210-265.

[12] Harker, A. (1909) The Natural History of Igneous Rocks. Methuen and Co., London, 344 p.

[13] Chappell, B.W. and White, A.J.R. (1992) I- and S-Type Granites in Lachlan Fold Belt. Transactions of the Royal Society of Edinburgh: Earth Sciences, 83, 1-26. http://dx.doi.org/10.1017/S0263593300007720

[14] Rollinson, H. (1993) The Geochemistry of Mafic and Ultramafic Rocks from the Archaen Greenstone Belts of Sierra Leone. Mineralogical Magazine, 47, 267-280. http://dx.doi.org/10.1180/minmag.1983.047.344.01 
[15] Boynton, W.V. (1984) Cosmochemistry of the Rare Earth Elements: Meteorite Studies. In: Henderson, P., Ed., Rare Earth Element Geochemistry, Elsevier, Amsterdam, 63-114.

[16] Henderson, P. (1984) Rare Earth Element Geochemistry. Elsevier Science Publishers B.V., Amsterdam, 510 p.

[17] Sun, S. and McDonough, W.F. (1989) Chemical and Isotopic Systematic of Oceanic Basalts: Implications for Mantle Composition and Processes. Geological Special Publication, No. 42, 313-345.

[18] Kelement, P.B., Jonson, K.T.M., Kinzler, R.J. and Irving, A.J. (1990) High-Fied-Strength Element Depletion in Arc Basalts Due to Mantle-Magma Interaction. Nature, 345, 521-524. http://dx.doi.org/10.1038/345521a0

[19] Wilson, R. (1990) Paralomis Otsuae, a New Species of the Decapoda Anomura from Deep Waters off the Chilean Coast. Crustaceana, 58, 130-135. http://dx.doi.org/10.1163/156854090X00039

[20] Rapp, R.P. and Watson, E.B. (1995) Dehydration Melting of Metabasalt at 8 - 32 kbar: Implications for Continental Growth and Crust-Mantle Recycling. Journal of Petrology, 36, 891-931. http://dx.doi.org/10.1093/petrology/36.4.891

[21] Chappell, B.W. and White, A.J.R. (1974) Two Contrasting Granite Types. Pacific Geology, 8, 237-253.

[22] Douce, A.E.P. (1999) Generation of Granitoids. Geology 25.

[23] Pearce, J.A., Harris, N.B.W. and Tindle, A.G. (1984) Trace Element Discrimination Diagrams for the Tectonic Interpretation of Granitic Rocks. Journal of Petrology, 25, 965-983. http://dx.doi.org/10.1093/petrology/25.4.956

[24] Pearce, J. (1996) Source and Setting of Granitic Rocks. Episode, 19, 120-125.

[25] Maniar, P.D. and Piccoli, P.M. (1989) Tectonic Discrimination of Granitoids. Geological Society of America Bulletin, 101, 635-643.

[26] Mullen, E.D. (1983) $\mathrm{MnO} / \mathrm{TiO}_{2} / \mathrm{P}_{2} \mathrm{O}_{5}$ : A Minor Element Discriminant for Basaltic Rocks of Oceanic Environment and Its Implications for Petrogenesis. Earth and Planetary Science Letters, 62, 53-62. http://dx.doi.org/10.1016/0012-821X(83)90070-5

[27] Meschede, M. (1986) A Method of Discriminating between Different Types of Mid-Ocean Ridge Basalt and Continental Tholeiites with the Nb-Zr-Y Diagram. Chemical Geology, 56, 207-218. http://dx.doi.org/10.1016/0009-2541(86)90004-5

[28] Davoudian, A.R., Hamedani, A., Shabanian, N. and Mackizadeh, M.A. (2007) Petrological and Geocemical Constraints on the Evolution of the Cheshmeh-Sefid Granitoid Complex of Golpayegan in the Sanandaj-Sirjan Zone. Neues Jahrbuch für Mineralogie-Abhandlungen: Journal of Mineralogy and Geochemistry, 184, 117-129. 
Scientific Research Publishing (SCIRP) is one of the largest Open Access journal publishers. It is currently publishing more than 200 open access, online, peer-reviewed journals covering a wide range of academic disciplines. SCIRP serves the worldwide academic communities and contributes to the progress and application of science with its publication.

Other selected journals from SCIRP are listed as below. Submit your manuscript to us via either submit@scirp.org or Online Submission Portal.
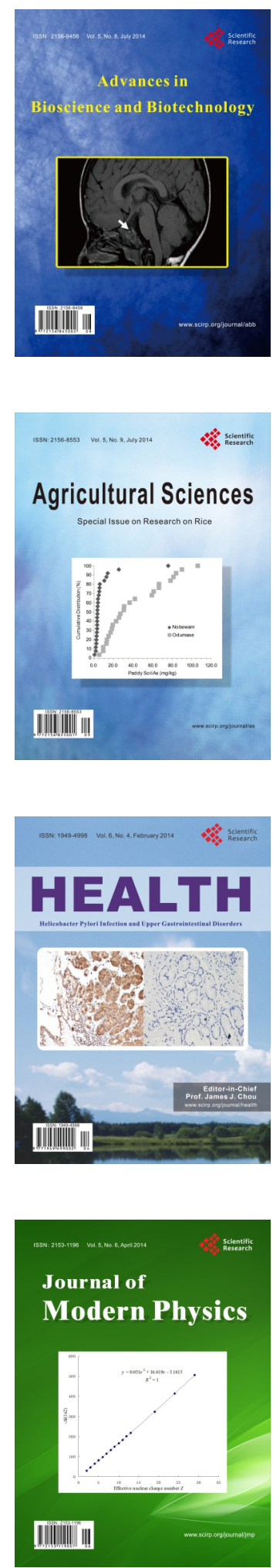
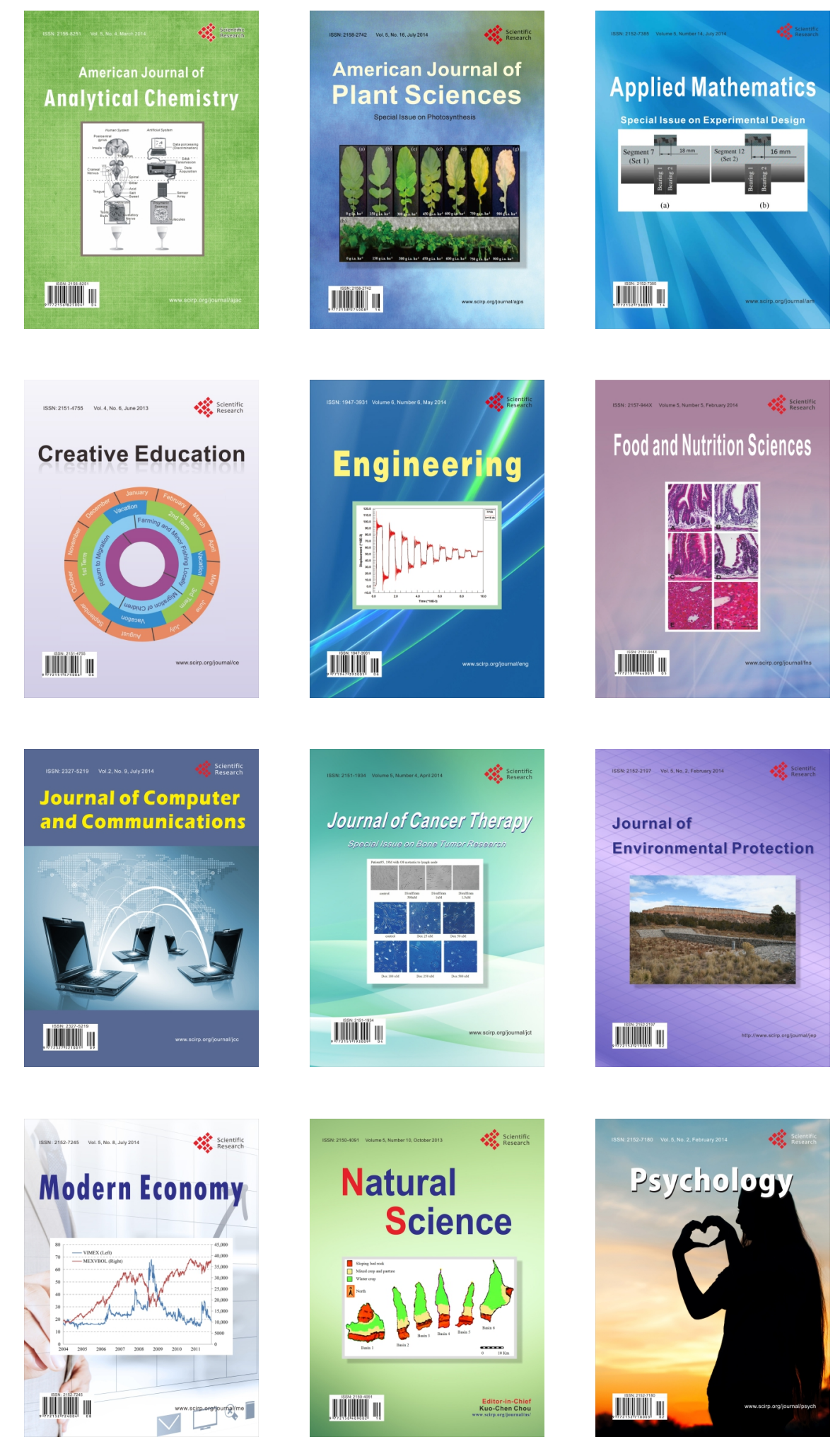